\title{
Michel's Transport Medium as an Alternative to Liquid Nitrogen for PCR Analysis of Skin Biopsy Specimens
}

\author{
Logeina Boraiy Lionel Fontao \\ Departments of Dermatology and Laboratory Medicine, Geneva University Hospital, \\ Geneva, Switzerland
}

Key Words

Michel's medium · PCR · Skin biopsy $\cdot$ DNA

\section{Abstract}

Formalin fixation and paraffin embedding are standard procedures for histopathological diagnosis and allow long-term archiving of tissue specimens. The cross-linking properties of formalin cause fragmentation of nucleic acids and reduce the sensitivity of PCR analysis. Michel's medium is a well-established transport medium used by dermatologists for biopsy transport to maintain tissue-fixed immunoreactants prior to direct immunofluorescence and immunoelectron microscopy. Here we report that Michel's medium also allows short-term preservation of DNA for PCR analysis and permits amplification of amplicons larger than $1 \mathrm{~kb}$. Therefore, Michel's medium appears to be a reserve medium for performing PCR when no other samples are available.

\section{Introduction}

Formalin fixation and paraffin embedding (FFPE) are standard procedures for histopathological diagnosis and allow long-term archiving of tissue specimens. Unfortunately, the cross-linking properties of formalin cause fragmentation of nucleic acids and reduce the quality of DNA extracted from FFPE, which may result in low sensitivity of PCR tests in some samples [1]. Thus, the gold standard for molecular analysis remains fresh-frozen tissue, 
which is not convenient for specimen conservation and transportation. In dermatology, an alternative conservation and transport medium commonly used is Michel's transport medium. This medium, initially described by Michel et al. [2] in 1972, has been simplified by Niedecken and Lange [3] and is currently used by most dermatologists for biopsy transport to laboratories for the detection of tissue-bound immunoreactants by direct immunofluorescence microscopy (DIF) [4-6]. More recently, normal saline was shown to be an alternative to Michel's transport medium for DIF studies, but it can only be used if the specimens are transported to the laboratory within $24 \mathrm{~h}$ [7].

We wanted to assess whether DNA extracted from biopsies made for DIF and transported in various transport media including Michel's transport medium was equally suited for molecular testing by PCR.

\section{Materials and Methods}

\section{Tissue Samples}

All samples were from the dermatology laboratory at the Geneva University Hospital (table 1). Twelve biopsies in Michel's medium (55 $\mathrm{g} \mathrm{NH}_{4} \mathrm{SO}_{4}$ per $100 \mathrm{ml} \mathrm{0.9 \%} \mathrm{NaCl,} \mathrm{pH} \mathrm{7.4)}$ [3] and 7 biopsies in $0.9 \% \mathrm{NaCl}$ were sent for DIF by dermatologists outside of the Hospital. Specimens in Michel's medium and in $0.9 \% \mathrm{NaCl}$ were sent by regular mail and arrived at the laboratory within 3 days after sending. These specimens were rinsed in PBS for $3 \times 10 \mathrm{~min}$ and frozen at $-20^{\circ} \mathrm{C}$. Twelve biopsies were from patients examined at the dermatology clinic, Geneva University Hospital. Specimens were transferred to cryotubes, snap-frozen in liquid nitrogen and transported in liquid nitrogen to the laboratory and immediately stored at $-20^{\circ} \mathrm{C}$. All specimens were embedded in OCT and used for DIF. After sectioning, samples were covered with OCT and archived at $-20^{\circ} \mathrm{C}$ prior to being used for DNA extraction.

\section{DNA Extraction}

DNA was extracted and purified as previously described by Yehia et al. [8] with minor modifications. Five to ten cryosections of $10 \mu \mathrm{m}$ were harvested from each OCT block in precooled tubes and lysed in $400 \mu \mathrm{l}$ cell lysis solution (Qiagen). $30 \mu \mathrm{g}$ of proteinase $\mathrm{K}$ was added to each sample. Following brief vortexing, the samples were incubated overnight under shaking at $56^{\circ} \mathrm{C}$. After a 30 -min incubation at $37^{\circ} \mathrm{C}$ with RNAse A ( $20 \mu \mathrm{g} /$ tube), samples were spun at $13,000 \mathrm{~g}$ for $5 \mathrm{~min}$ to remove residual debris. The supernatant was collected and cooled on ice for $1 \mathrm{~min}$, and $133 \mu \mathrm{l}$ of protein precipitation solution (Qiagen) were added. After vortexing, samples were left on ice for at least $20 \mathrm{~min}$ and then centrifuged at $13,000 \mathrm{~g}$ for $5 \mathrm{~min}$. The supernatant containing DNA was transferred to a new tube, and the DNA was precipitated by the addition of $400 \mu \mathrm{l}$ of $100 \%$ isopropanol and $1 \mu \mathrm{l}$ of glycogen solution (20 $\mathrm{mg} / \mathrm{ml}$; Qiagen). After mixing and centrifugation at 13,000 $\mathrm{g}$ for $5 \mathrm{~min}$, the pellet of DNA was washed twice with $70 \%$ ethanol, dried and resuspended in $30 \mu \mathrm{l}$ of $10 \mathrm{~mm}$ Tris buffer, $\mathrm{pH}$ 8.5.

\section{$P C R$}

PCR was performed with genomic DNA using 35 cycles for each primer set with Taq DNA polymerase (Life Technologies) in a final volume of $25 \mu$ l. Water instead of DNA template was used for negative controls. The $\beta$-globin gene (HBB) was amplified using the GH20 (5'-GAA GAG CCA AGG ACA GGT AC- $3^{\prime}$ ) and PCO4 ( $5^{\prime}$-CAA CTT CAT CCA CGT TCA CC-3') primer sets [9] with the following PCR conditions: $96^{\circ} \mathrm{C} / 30 \mathrm{~s}, 55^{\circ} \mathrm{C} / 30 \mathrm{~s}, 72^{\circ} \mathrm{C} / 30 \mathrm{~s}$. The type I collagen gene (COL1A1) was amplified using the ex48 (5'-CCA CCT CAA GAG AAG GCT CAC GA- $3^{\prime}$ ) and re52 (5'-TGG GAT GGA GGG AGT TTA CA-3') primer sets [10] with the following PCR conditions: $96^{\circ} \mathrm{C} / 30 \mathrm{~s}, 55^{\circ} \mathrm{C} / 30 \mathrm{~s}, 72^{\circ} \mathrm{C} / 95 \mathrm{~s}$. 
Table 1. DNA was extracted from different specimens for each of the various transport media

\begin{tabular}{|c|c|c|c|c|c|c|c|c|c|}
\hline $\begin{array}{l}\text { Sample } \\
\text { ID }\end{array}$ & Transport medium & Sex & $\begin{array}{l}\text { Age, } \\
\text { years }\end{array}$ & $\begin{array}{l}\mathrm{DNA}, \\
\mathrm{ng} / \mu \mathrm{l}\end{array}$ & $\mathrm{A}_{260}$ & $\mathrm{~A}_{280}$ & $\mathrm{~A}_{260 / 280}$ & $\begin{array}{l}\text { PCR HBB } \\
268 \mathrm{bp}\end{array}$ & $\begin{array}{l}\text { PCR COL1A1 } \\
1,360 \mathrm{bp}\end{array}$ \\
\hline MM1 & Michel's medium & M & 63 & 17.92 & 0.358 & 0.199 & 1.8 & positive & positive \\
\hline MM2 & Michel’s medium & $\mathrm{F}$ & 41 & 9.96 & 0.199 & 0.086 & 2.32 & positive & positive \\
\hline MM3 & Michel's medium & $\mathrm{F}$ & 79 & 3.35 & 0.067 & 0.026 & 2.57 & positive & positive \\
\hline MM4 & Michel's medium & $\mathrm{F}$ & 38 & 26.16 & 0.523 & 0.289 & 1.81 & positive & positive \\
\hline MM5 & Michel's medium & M & 91 & 6.92 & 0.138 & 0.071 & 1.95 & positive & positive \\
\hline MM6 & Michel's medium & M & 91 & 12.13 & 0.243 & 0.113 & 2.14 & positive & positive \\
\hline MM7 & Michel's medium & M & 63 & 23.06 & 0.461 & 0.263 & 1.75 & positive & positive \\
\hline MM8 & Michel’s medium & M & 57 & 16.59 & 0.332 & 0.184 & 1.8 & positive & positive \\
\hline MM9 & Michel's medium & $\mathrm{F}$ & 75 & 12.39 & 0.248 & 0.148 & 1.68 & positive & positive \\
\hline MM10 & Michel's medium & M & 35 & 7.47 & 0.149 & 0.062 & 2.41 & positive & positive \\
\hline MM11 & Michel's medium & $\mathrm{F}$ & 89 & 6.41 & 0.128 & 0.071 & 1.81 & positive & positive \\
\hline MM12 & Michel's medium & $\mathrm{F}$ & 83 & 7.65 & 0.153 & 0.069 & 2.2 & positive & positive \\
\hline LN1 & Liquid nitrogen & M & 61 & 43.24 & 0.865 & 0.467 & 1.85 & positive & positive \\
\hline LN2 & Liquid nitrogen & M & 57 & 13.12 & 0.262 & 0.133 & 1.97 & positive & positive \\
\hline LN3 & Liquid nitrogen & $\mathrm{F}$ & 59 & 7.98 & 0.16 & 0.069 & 2.32 & positive & positive \\
\hline LN4 & Liquid nitrogen & $\mathrm{F}$ & 53 & 15.18 & 0.304 & 0.169 & 1.79 & positive & positive \\
\hline LN5 & Liquid nitrogen & $\mathrm{F}$ & 45 & 21.72 & 0.434 & 0.239 & 1.82 & positive & positive \\
\hline LN6 & Liquid nitrogen & M & 72 & 13.42 & 0.268 & 0.182 & 1.47 & positive & positive \\
\hline LN7 & Liquid nitrogen & M & 78 & 20.73 & 0.415 & 0.23 & 1.8 & positive & positive \\
\hline LN8 & Liquid nitrogen & $\mathrm{F}$ & 51 & 8.02 & 0.16 & 0.077 & 2.08 & positive & positive \\
\hline LN9 & Liquid nitrogen & M & 38 & 6.25 & 0.125 & 0.067 & 1.87 & positive & positive \\
\hline LN10 & Liquid nitrogen & M & 59 & 10.34 & 0.207 & 0.109 & 1.9 & positive & positive \\
\hline LN11 & Liquid nitrogen & M & 33 & 9.71 & 0.194 & 0.106 & 1.83 & positive & positive \\
\hline LN12 & Liquid nitrogen & $\mathrm{F}$ & 58 & 5.43 & 0.109 & 0.052 & 2.1 & positive & negative \\
\hline NaCL1 & $0.9 \% \mathrm{NaCl}$ & $\mathrm{F}$ & 66 & 6.33 & 0.127 & 0.056 & 2.26 & positive & negative \\
\hline NaCL2 & $0.9 \% \mathrm{NaCl}$ & M & 61 & 11.39 & 0.228 & 0.12 & 1.9 & positive & positive \\
\hline $\mathrm{NaCL3}$ & $0.9 \% \mathrm{NaCl}$ & $\mathrm{F}$ & 66 & 28.72 & 0.574 & 0.305 & 1.88 & positive & positive \\
\hline $\mathrm{NaCL} 4$ & $0.9 \% \mathrm{NaCl}$ & $\mathrm{F}$ & 51 & 48.78 & 0.976 & 0.52 & 1.88 & negative & positive \\
\hline NaCL5 & $0.9 \% \mathrm{NaCl}$ & M & 53 & 11.23 & 0.225 & 0.116 & 1.94 & positive & positive \\
\hline NaCL6 & $0.9 \% \mathrm{NaCl}$ & M & 38 & 13.17 & 0.263 & 0.134 & 1.96 & positive & positive \\
\hline
\end{tabular}

Absorbance was measured by spectrophotometer (Nanodrop ND1000), and nucleic acid sample purity was assessed by ratios of absorbance at $260 \mathrm{~nm} / 280 \mathrm{~nm}\left(\mathrm{~A}_{260 / 280}\right) . \mathrm{A}_{260 / 280}$ of 1.8 or greater is generally accepted as 'pure' for DNA. If the ratio is appreciably lower, it may indicate the presence of protein or other contaminants that absorb strongly at or near $280 \mathrm{~nm}$.

\section{Results}

Extracted DNA was quantified by absorbance and evaluated for impurities by ratios of absorbance at $260 \mathrm{~nm} / 280 \mathrm{~nm}\left(\mathrm{~A}_{260 / 280}\right)$ for residual protein contaminants. As shown in table 1 , the DNA yield varied considerably among the different samples, probably because the cross-sectional tissue area and number of sections used for DNA extraction were different. An average of $14.6,12.5$ and $19.9 \mathrm{ng} / \mu \mathrm{l}$ of DNA was obtained for biopsies transported in liquid nitrogen, Michel's medium or normal chloride, respectively. The transport medium did not significantly influence sample purity as measured by $\mathrm{A}_{260 / 280}$ ratios, with an average ratio above 1.8 for all of them indicating a minor contamination of DNA by proteins (table 1).

Amplification of small PCR products is sufficient for the diagnosis of skin infection such as syphilis, lyme borreliosis, leishmaniasis or tuberculosis as well as for lymphoma $[11,12]$. Therefore, we assessed whether the quality of the extracted DNA was sufficient to allow PCR amplification of a 268-bp DNA fragment from the HBB gene and of 1,360 bp from the COL1A1 
Boraiy and Fontao: Michel's Transport Medium as an Alternative to Liquid Nitrogen for PCR Analysis of Skin Biopsy Specimens

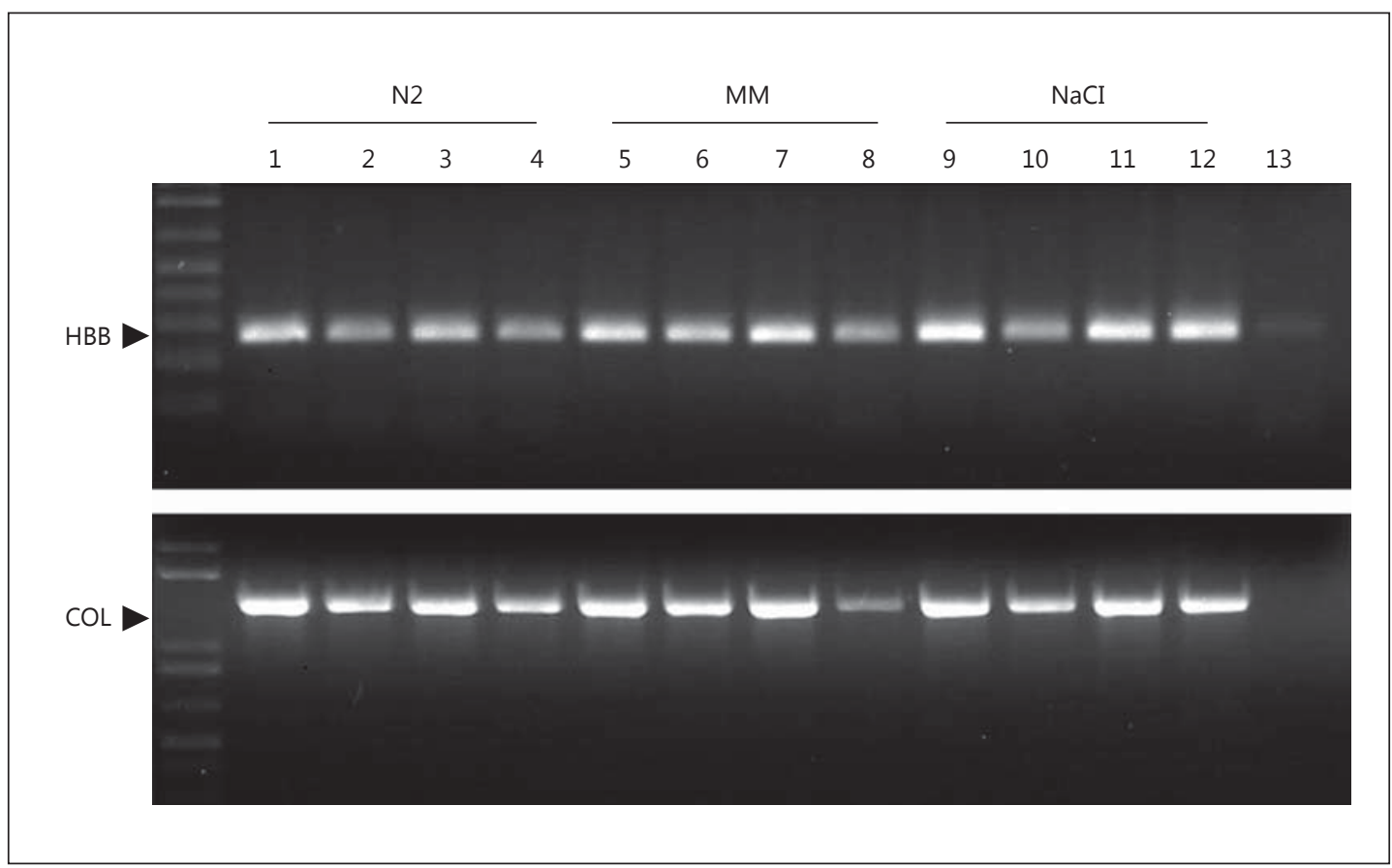

Fig. 1. Agarose gel electrophoresis of PCR amplicons after amplification of the HBB gene and COL1A1 gene (COL) from DNA prepared from skin biopsies transported in liquid nitrogen (N2), Michel's transport medium (MM) or normal saline (NaCl). 40 ng (lanes 1, 3, 5, 7, 9, 11) or 8 ng (lanes 2, 4, 6, 8, 10, 12) of total DNA was used as template in PCR. Lane 13 = Negative control.

gene. In a first series of PCR, $2 \mu \mathrm{l}$ of purified DNA were used for PCR. As shown in table 1, most samples gave positive results for both genes, indicating that the transport medium did not significantly influence PCR efficacy. Next, PCR reactions were performed using a similar amount of template, 40 and $8 \mathrm{ng}$, from each of the fixation methods to emphasize any differences in sample quality. As shown in figure 1, all samples gave positive results with 40 and $8 \mathrm{ng}$ of template.

\section{Discussion}

Michel's medium is a well-established transport medium used to maintain tissue-fixed immunoreactants prior to DIF, immunoelectron microscopy and epitope mapping for genodermatoses [13]. This transport medium probably preserves immuno-antigenicity by its ability to precipitate macromolecules while inhibiting proteolytic enzymes [2]. Here we report that no significant differences exist among liquid nitrogen, Michel's medium and normal chloride for short-term preservation of DNA for PCR analysis. We showed that as little as $8 \mathrm{ng}$ of template DNA purified from sample in Michel's transport medium are sufficient for PCR amplification of amplicons larger than $1 \mathrm{~kb}$. This contrasts with the results obtained with FFPE samples with formalin fixation causing fragmentation of nucleic acids that results in amplicons no larger than 500 bp $[1,14]$. Furthermore, we found no obvious inhibitory effects of Michel's medium on PCR efficacy in the 12 tested samples. Thus, Michel's medium appears to be a reserve medium for performing PCR when no other samples are available. 


\section{Acknowledgements}

We thank Mrs. Evelyne Leemans, Catherine Fasel-Remondat and Mr. Stephane Martins from the laboratory of dermatology for their technical help, and Dr. Emmanuel Laffitte for helpful discussion.

\section{References}

1 Stanta G, Mucelli SP, Petrera F, Bonin S, Bussolati G: A novel fixative improves opportunities of nucleic acids and proteomic analysis in human archive's tissues. Diagn Mol Pathol 2006;15:115-123.

2 Michel B, Milner Y, David K: Preservation of tissue-fixed immunoglobulins in skin biopsies of patients with lupus erythematosus and bullous diseases - preliminary report. J Invest Dermatol 1972;59:449-452.

-3 Niedecken HW, Lange CE: Simplified fixative medium for direct immunofluorescence in skin biopsies. J Am Acad Dermatol 1985;12:828-831.

-4 Pique-Duran E, Palacios-Llopis S, de la Rosa-del Rey P, Recio-Anon C: Michel's transport medium for immunofluorescence (in Spanish). Actas Dermosifiliogr 2007;98:376.

5 Vaughn Jones SA, Palmer I, Bhogal BS, Eady RA, Black MM: The use of Michel's transport medium for immunofluorescence and immunoelectron microscopy in autoimmune bullous diseases. J Cutan Pathol 1995;22: 365-370.

-6 Vaughan Jones SA, Salas J, McGrath JA, Palmer I, Bhogal GS, Black MM: A retrospective analysis of tissue-fixed immunoreactants from skin biopsies maintained in Michel's medium. Dermatology 1994;189(suppl 1):131132.

-7 Vodegel RM, de Jong MC, Meijer HJ, Weytingh MB, Pas HH, Jonkman MF: Enhanced diagnostic immunofluorescence using biopsies transported in saline. BMC Dermatol 2004;4:10.

-8 Yehia L, Adib-Houreih M, Raslan WF, Kibbi AG, Loya A, Firooz A, Satti M, El-Sabban M, Khalifeh I: Molecular diagnosis of cutaneous leishmaniasis and species identification: analysis of 122 biopsies with varied parasite index. J Cutan Pathol 2012;39:347-355.

-9 Zollinger T, Mertz KD, Schmid M, Schmitt A, Pfaltz M, Kempf W: Borrelia in granuloma annulare, morphea and lichen sclerosus: a PCR-based study and review of the literature. J Cutan Pathol 2009;37:571-577.

-10 Patel KU, Szabo SS, Hernandez VS, Prieto VG, Abruzzo LV, Lazar AJ, Lopez-Terrada D: Dermatofibrosarcoma protuberans COL1A1-PDGFB fusion is identified in virtually all dermatofibrosarcoma protuberans cases when investigated by newly developed multiplex reverse transcription polymerase chain reaction and fluorescence in situ hybridization assays. Hum Pathol 2008;39:184-193.

11 Brettschneider S, Bruckbauer H, Klugbauer N, Hofmann H: Diagnostic value of PCR for detection of Borrelia burgdorferi in skin biopsy and urine samples from patients with skin borreliosis. J Clin Microbiol 1998;36: 2658-2665.

12 Theriault C, Galoin S, Valmary S, Selves J, Lamant L, Roda D, Rigal-Huguet F, Brousset P, Delsol G, Al Saati T: PCR analysis of immunoglobulin heavy chain (IgH) and TcR-gamma chain gene rearrangements in the diagnosis of lymphoproliferative disorders: results of a study of 525 cases. Mod Pathol 2000;13:1269-1279.

-13 Woollons A, Holmes GJ, Gratian MJ, Bhogal BS, Black MM: Michel's medium: a potential alternative to cryoprotection for tissue transport in the investigation of genetic skin disease. Clin Exp Dermatol 1999;24:487-489.

14 Moelans CB, Oostenrijk D, Moons MJ, van Diest PJ: Formaldehyde substitute fixatives: effects on nucleic acid preservation. J Clin Pathol;64:960-967. 